\title{
Jurist-Diction
}

Volume 4 No. 6 November 202

\section{Media Sosial Sebagai Alat Tindak Pidana Makar}

\author{
Vicky Yuliana Saputri \\ vicky.yuliana.saputri-2017@fhunair.ac.id \\ Universitas Airlangga
}

How to cite:

Vicky Yuliana Saputri 'Media Sosial Sebagai Alat Tindak Pidana Makar' (2021) Vol. 4 No. 6 Jurist-Diction.

Histori artikel:

Submit 6 Mei 2021;

Diterima 15 Oktober 2021;

Diterbitkan 5 November 2021

DOI:

10.20473/jd.v4i6.31856

p-ISSN: 2721-8392

e-ISSN: $2655-8297$

\section{Abstract}

In Indonesia, the replacement of the President is regulated in article $6 A$ of the 1945 Constitution, if this provision is violated it will result in an unlawful act. Not only this article but also contained in article $7 A$ of the 1945 Constitution. Technology at this time has experienced a very large development, social media is used by the public to convey information. Lately, many phenomena in the form of dismissal and the desire to assassinate the president have been carried out in cyberspace. Then what is the criminal responsibility for acts committed using social media. Considering that a criminal act if the act is committed or only an act of planning can have fatal consequences, and the treason articles can be applied, namely article 104, article 106 and article 107 of the Criminal Code.

Keywords: Criminal Act of treason; Social Media; Criminal Liability.

\begin{abstract}
Abstrak
Di Indonesia dalam penggantian Presiden diatur dalam pasal 6A Undang-Undang Dasar 1945, jika ketentuan tersebut dilanggar maka akan mengakibatkan perbuatan melawan hukum. Tidak hanya pasal tersebut namun juga terdapat dalam pasal 7A Undang-Undang Dasar 1945.Teknologi pada masa saat ini mengalami perkembangan yang sangat besar, media sosial digunakan masyarakat untuk menyampaikan informasi. Belakangan ini banyak sekali fenomena berupa pemberhentian dan keinginan untuk membunuh presiden dilakukan di dunia maya. Lalu bagaimana pertanggungjawaban pidana atas perbuatan yang dilakukan menggunakan media sosial tersebut. Mengingat tindak pidana bila perbuatan itu dilakukan atau hanya perbuatan perencanaan dapat berakibat fatal, dan dapat diberlakukan pasal-pasal makar yaitu pasal 104, pasal 106 dan pasal 107.

Kata Kunci: Tindak Pidana Makar; Media Sosial; Pertanggungjawaban Pidana.
\end{abstract}

Copyright $@ 2021$ Vicky Yuliana Saputri

\section{Pendahuluan}

Tindak Pidana makar di Indonesia mengalami perkembangan dari zaman ke zaman, motifnya pun juga sangat beragam mulai dari balas dendam, menginginkan kekuasaan dan juga ingin menggantikan kepemimpinan yang ada saat ini. Tindak Pidana Makar yang terkenal di Indonesia adalah G30 S dimana dalam perbuatan tersebut banyak para petinggi Angkatan Darat yang mati, Peristiwa ini sebenarnya 
tidak memiliki arahan yang tepat, sehingga pelaku dalam tindak pidana makar ini dijatuhi hukuman mati. ${ }^{1}$ Dimasa sekarang ini teknologi berkembangkan yang sangat pesat, sehingga berkembanglah cybercrime yang merupalan kasus yang memiliki ruang lingkup yang sangat luas bahkan mencangkup dunia internasional. Banyak sekali fenomena- fenomena yang berkembang di media sosial pada akhir-akhir ini, yaitu beredarnya video yang berupa ajakan untuk membuat pemerintahan tidak berdaya, mengepung gedur DPR/ MPR, keinginan untuk membunuh Presiden, ingin melepaskan diri dari NKRI, bahkan tidak mengakui pemerintahan yang saat ini sedang berlangsung, hal-hal tersebut dapat di kategorikan sebagai tindak pidana makar walaupun dilakukan dengan menggunakan media sosial. ${ }^{2}$

Undang-undang Informatika dan Transaksi Elektronik menjadikan dasar dalam penangkapan dan banyak sekali bukti yang dapat digunakan, selain itu pasalpasal tentang keamanan negara dapat juga diterapkan guna untuk membenahi apa yang beredar di media sosial tersebut. ${ }^{3}$ Gejolak politik yang ada akhir-akhir ini yang menimbulkan banyak sekali tindak pidana makar yang dilakukan oleh masyarakat tanpa sadar, seperti pada Putusan Pengadilan Nomor 1116/Pid.B/2019/PN Jkt.Pst dalam kasus tersebut sarana yang digunakan oleh terdakwa adalah media sosial, dan bentuk dari kejahatannya adalah penyebaran video melalui aplikasi Whatapps .

\section{Metode Penelitian}

Penelitian ini menggunakan penelitian normatif. Penelitian normatif merupakan penelitian yang sumber utamanya menelaah konsep, asas dan norma yang berkaitan dengan tema yang sedang diteliti. Penelitian normatif disebut juga dengan penelitian kepustakaan baik primer maupun sekunder dan penelitian ini memiliki sifat preskriptif.

\footnotetext{
${ }^{1}$ Petrik Matanasi, "Sejarah Panjang Usaha Makar di Indonesia”, (Tirto.id, 2016) https:// www.google.com/amp/s/amp.tirto.id diakses pada 27 Januari 2021.

2 Erdianto Effendi, 'Makar dengan Modus Menggunakan Media Sosial' (2019) 1 Jurnal Hukum Pidana Dan Pembangunan Hukum. [8].

${ }^{3}$ ibid.
} 


\section{Konsep Makar Dalam KUHP}

Pada buku ke-dua bab ke 1 KUHP terdapat tindak pidana makar. Makar sendiri dalam kamus hukum diartikan sebagai perbuatan untuk membunuh dan atau mengambil kemerdekaan kepala negara atau membuat kepala negara tidak mampu memerintah. ${ }^{4}$ Dalam KUHP juga terdapat istilah makar yaitu dalam pasal 87 KUHP disebutkan bahwa dikatakan makar apabila niat tersebut dinyatakan melalui perbuatan permulaan pelaksanaan seperti yang terdapat dalam pasal 53 KUHP. Dengan demikian pemidanaan kepada pelaku yang pernuatannya di kategorikan sebagai kejahatan makar cukup dengan terpenuhinya permulaan pelaksanaan yang telah dilarang oleh undang-undang tanpa dipenuhinya syarat tidak selesai pelaksanaan bukan semata-mata sidebabkan oekh kehendaknya sendiri.

Unsur yang harus terprnuhi dalam pasal 87 KUHP adalah niat dan juga permulaan pelaksanaan. Niat disini dapat dilihat dari kesengajaan yang dilakukan oleh pelaku yang mengetahui dan juga menghendaki yang dilakukannya itu. Pada pasal 53 tidak memberikan penjabaran tentang niat namun meliputi dolus eventualis. ${ }^{5}$ Sedangkan untuk permulaan pelaksanaan ini didahulukan dengan niat ataupun kehendaknya, menurut pendapat dari Simos perbuatan pelaksanaan adalah pertama delik yang dirumuskan secara formal yang perbuatannya telah dirumuskan dalam undang-undang yang kedua adalah delik secara meterial perbuatannya dilakukan yeng menurut sifatnya menimbulkan akibat yang telah dilarang oleh undang-undang. ${ }^{6}$ Tindak pidana makar memiliki 3 bentu yaitu makar terhadap nyawa atu kemerdekaan Presiden atau wakil persiden hal inidiatur dalam pasal 104 KUHP, makar terhadao wilayah negara yang diatur dalam pasal 106 KUHP dan makar terhadap pemerintahan yang diatur dalam pasal 107 KUHP. Sebenarnya KUHP tidak memberikan definisi terhadao makar akan tetapi ketenuannya terdapat dalam pasal 104,106,107, 139a, 139b menyebutkan secara tegas perbuatan mana

\footnotetext{
${ }^{4}$ Charlie Rudyat, Kamus Hukum (Tim pustaka Mahardika 2013).[299].

${ }^{5}$ Moeljatno, Hukum Pidana Delik-Delik Percobaan dan Delik-Delik Penyertaan (PT Bina Aksara 1983).[16].

${ }^{6}$ Djoko Prakoso, Tindak Pidana Makar Menurut KUHP (Ghalia Indonesia 1985).[23-24].
} 
yang dikategorikan sebagai tindak pidana makar dan pasal 87 KUHP juga merujuk pasa pasal 53 ayat 1 KUHP tentang percobaan. Makar yang memenuhi pasal 53 ayat 1 memenuhi syarat pertama danjuga syarat yang kedua dan pelaku dapat dipidana dengan pasal makar cukup dengan adanya niat dan adanya permulaan pelaksanaan serta adanya maksud tertentu yang dilarang oleh undang-undang, dan syarat tidak selesainya bukan semata-mata karena kehendaknya sendiri tidak harus terpenuhi.

Delik Makar ini berbeda dengan delik pemberontakan yang ada dalam pasal 108 KUHP, Tujuan dari rindak pidana makar ini telah tercermin dalam pasal 104, pasal 105 dan pasal 107 KUHP sedangkan pasal 108 KUHP ada unsur yang harus dipenuhi yaitu unsur melawan pemerintah menggunakan senjata. Putusan Mahkamah Konstitusi Nomor 7/PUU-XV/2017 menyatakan bawa dapat diduga pelaku tindak pidana makar menurut rumusan pasal 87 KUHP adalah cukup dengan dua syarat saja yaitu niat dan permulaan pelaksanaan. ${ }^{7}$ Dan dalam putusan tersebut pula pasal 87 KUHP, pasal 104 KUHP, pasal 106 KUHP, pasal 107 KUHP, pasal 139a KUHP, pasal 139b KUHP dan pasal 140 KUHP tidak bertntangan dengan Undang-Undang Dasar yaitu pasal $28 \mathrm{D}$ ayat 1 dan pasal $28 \mathrm{G}$ ayat 1 dikarenakan pasal 87 KUHP tersebut digunakan untuk melindungi kepentingan negara.

Tindak pidana makar erat kaitanya dengan permufakatan jahat, dan permufakatan jahat ini diklasifikasikan dalam kejahatan yang ada dalam pasal 104 KUHP, pasal 106 KUHP, pasal 107 KUHP, pasal 108 KUHP yang dirumuskan kedalam pasal 110 KUHP. Permusakatan jahat ini mengandung unsur-unsur yakni adanya dua orang arau lebih, memiliki kesepakata dan juga melakukan kejahatan ini merupakan isi dari kesepakatan tersebut pada pasal 88 KUHP pemufakatan jahat in pada dasarnya belum merupakan tindak pidana. Pada pasal 110 KUHP ini yaitu pemufakatan yag ada dalam pasal 110 ayat 1 KUHP sebagaimana kejahatan ini sesuai dengan yang ada dalam pasal 104, pasal 106, pasal 107 dan pasal 108 KUHP merupakan bentuk permufakatan untuk melakukan kejahatan sesuai dengan pasal tersebut, sedangkan untuk pasal 110 ayat 2 terdapat unsur perbuatan yaitu persiapan

${ }^{7}$ Mahkamah Konstitusi RI, Putusan Nomor 7/PUU-XV/2017, https://mkri.id, diakses pada 10 Desember 2020. 
kejahatan dan juga memperlancar kejahatan dalam hal tersebut menggerakkan , menyuruh menggerakkan, menyuruh melakukan, turut serta melakukan, membantu dan memberi kesepakatan, memberi sarana dan juga kesempatan hal ini sama dengan pasal 55 dan pasal 56 KUHP bentuk dari penyertaan.

\section{Media Sosial Sebagai Sarana}

Media sosial merupakan ruang yang digunakan oleh masyarakat luas untuk berinteraksi dengan orang lain, Menurut pendapat dari Van Dijk Media sosial merupakan platform online yang memiliki fokus untuk menfasilitasi masyarat yang menngunakannya. ${ }^{8}$ Dengan berkembangnya media sosial ini tanpa sadar masyarakat masuk dalam jerat hukum dengan mudah yaitu dengan postingan ataupun ketikan yang dilakukan oleh seseorang dimana orang tersebut membagikan melalui media sosial, media sosial ini dikategorikan sebagai mernuataan di ruang publik. Media sosial yang merupakan ruang publik inilah menurut pendapat dari Habermas Ruang publik memiliki sifat yang tidak terbatas yang artinya ruang publik tidak tidak terbatas ruang ataupun waktu. Media sosial digolongkan ruang publik virtual yang memiliki sifat yang lebih luas, bebas dan terbuka yang menggunakan jaringan internet alam penggunaannya, pernyataan yang sudah masuk dalam media sosial merupakam pernyataan publik sehingga pernyataan yang hakikatnya mengandung perbuatan pada masal-pasal makar dalam KUHp jelas dapat dikaegorikan sebagai tindak pidana makar atau disebut juga dengan makar verbal.

Makar verbal berbeda dengan makar pada umumnya karena makar verbal ini mengunakan media sosial sebagao medianya, sehingga masyarakat tanpa sadar telah melakukannya. Hal ini dapat dilakukan menggunkan pernyataan- pernyataan, unggahan video, membagikan sesuatu yang dianggap telah bertantangan dengan pasal-pasal makar yang ada dalam KUHP khusunya pasal makar. Makar mengunakan media sosial ini menurut pendapat dari Lamintang dan Simon makar yang tidak mengunakan senjata dilakukan dengan serangan berupa pernyataan-

${ }^{8}$ Rulli Nasrullah, Media Sosial: Perspektif Komunikasi, Budaya, dan Sosioteknologi, (Remaja Rosdakarya 2017).[11]. 
pernytaan atau opini, dan tindakan yang menurut aparat penegak hukum masuk dalam kategori tindak pidana makar. Perbuatan yang terjadi dalam media sosial dapat dikategorikan sebagai perbuatan persiapan yang terdapat dalam Pasal 110 ayat (1) KUHP yaitu tentang permufakatan, dan Menurut pendapat dari Hibnu Nugoroho bahwa tindakan makar merupakan delik formil sehingga meskipun belum terjadi tindak pidananya tetap dapat menjadai awal tindak pidana makar. ${ }^{9}$ Menurut pendapat dari Indriyanto Seno Adji makar harus berbentuk ancaman atau kekerasan sebagai bentuk permulaan pelaksanaan maka yang terjadi didunia maya bukan termasuk dalam tindak pidana makar hal tersebut berbanding terbalik dari pendapat Nyon dan Langameiejer yang berpendapat apa yang dilakukan para tokoh di dunia maya yang sekarang beredar tersebut masuk kedalam tindak pidana makar.

Menurut pendapat dari Remelink sejalan dengan pedapat dari Hazewinkel yang dikutip oleh Loebby Loqman berpendapat bahwa pejabat politik memiliki suatu keyakinan bahwa mereka mempunyai pandangan hukum dan tata negara yang dianggap benar dan berbeda pandangan dengan pemerintah saat ini. Dengan pendapat yang demikian ini delik politik adalah delik yang ada dalam hukum pidana dan dirumuskan dengan motif politik yang dapat membahayakan kepentingan hukum tata negera. Unggahan yang adalam media internet juga harus diselidiki apakah sudah mengandung unsur niat dan permulaan pelaksanaan jika pembuat atau pengunggah yang ada di dalam media internet sudah mengetahui bahwasanya ungahan tersebut dapat menghasut publik maka dapat dikenai tindak pidana sesuai dengan yang dikatan R.Soesilo harutan yang dilakukan ditempat umum dimana orang dapat mendengar maka dapat dikenai tindak pidana yang ada dalam Pasal 106 KUHP. Dengan dikeluarkanya UndangUndang ITE diharapkan masyarakat lebih berhati-hati dalam mengunakan media sosial, karena pada akhir-akhir ini banyak terjadi peningkatan kejahatan yang dilakukan dalam media sosial ucapan yang tidak pantas untuk diucapkan yang

${ }^{9}$ Ardito Ramadhan, 'Sejumlah Tokoh Terjerat Pasal Makar, Begini Pandangan Ahli Hukum' (Kompas.com,2019) https://megapolitan.kompas.com, Dikunjungi tanggal 15 Desember 2020. 
dapat menggiring opini publik yang terekam baik secara audio maupun visual yang tersebar luas menggunakan media sosial yang sesuai dengan penjelasan Undang-Undang ITE pada ketentuan umum Pasal 1 angka 4 yang digunakan sebagai alat bukti dalam pembuktian persidangan.

Dalam media sosial terdapat larangan-larangan mengunakan media sosial diantaranya ditur dalam Pasal 27 Undang-Undang ITE yaitu larangan melanggar kesusilaan, Pasal 52 ayat (1) yaitu larangan adanya eksploitasi seksula terhadap anak, Pasal 27 ayat (2) yaitu larangan perjudian online, Pasal 27 ayat (3) yaitu larangan melakukan penghinaan dan juga pencemaran nama baik mengunakan sistem elektronik dan juga Pasal 28 ayat (2) yaitu larangan melakukan perbuatan yang menyebaran informasi bermuatan SARA. ${ }^{10}$ Unggarhan video yang terdapat dimedia sosial dapat dikategorikan sebagai permulaan pelaksanaan yang menurut pendapat dari Moeljatno delik makar masuk dalam delik percobaan, mencoba untuk melakukan tindak pidana dapat dikenai tindak pidana karena apat dilihat niat dari perbuatan tersebut dikarenakan tidak selesainya tindak pidana tersebut tidak dikarenakan kehendaknya sendiri. Permukaan pelaksanaan dapat ditafsirkan sebagai permulaan melakukan suatu kejahatan, menurut pendapat dari Wirjono Prodjodikoro yang berpendapat dengan Moerljatno bahwa makar yang ditunjukkan terhadap presiden maupun wakil presiden dapt dikategorikan sebagai delik percobaan dikarenakan dapat dilihat dari niat yang telah terlaksanaa dan oermulaan pelaksanaan. Menurut Eddy OS tang mengutip pendapat dari A Boers bahwa aanslag tidak dapat tiakrikan sebagai makar namun harus diartikan sebagai tindakan awal perbuatan. Menurut pendalat Moeljatno tindak pidana makar termasuk tindak pina yang selesai, walaupun hakikinya tindakan tersebut belum terselesaikan. Berdasarkan pendapat tersebut unggahan video yang didalamnya terdapat tindakan yang dapat dikaetegorikan sebagai tindak pidana makar masuk dalam tindak pidana makar karena makar erat kaitanya dengan keselamatan presiden dan wakil presiden, keamanan negara, dan pemerintahan yang sah dan berdaulat.

\footnotetext{
${ }^{10}$ Prima Angkupi, 'Kejahatan Melalui Media Sosial Elektronik Di Indonesia Berdasarkan Peraturan Perundang-Undangan Saat Ini’ (2014) 2 Jurnal Mikrotik.[5-6].
} 


\section{Konsep Pertangung Jwaban Pidana}

Roeslan Saleh berpendapat bahwa dalam pertanggungjawaban pidana didalamnya terdapat keadilan yang memiliki struktur yang jelas, hal ini karena pertangungjawaban pidana menyangkut tentang hukum pidana yang terjalit erat dengan keadailan sebagai filsafat. Disamping itu pertangungjawaban pidana adanya terus celaan obyektif dalam perbuatan pidan dan perbuatan tersebut dikategorikan sebagai perbuatan yang dilarang atau bertentangan dengan hukum material maupun hukum formil berbeda dengan celaan subyektif merujuk pada orang yang melakukan perbuatan yang bertentangan dengan hukum.

Asas yang terkandung dalam pertangungjawaban pidana ini adalah tidak adapat dipidana jika tidak ada keasalahan, oleh karena itu hukum pidana fiskal tidak memakai kesalahan jika ada orang yang melanggar ketentuan, dan hukuman yang diberikan berupa pidana denda ataupun rampasan. ${ }^{11}$ Dalam pertanggungjawaban pidana dikenal dengan mens rea hal ini berdasarkan dengan pemekiran dari orang yang melakukan tindak pidana tersebut, dalam hal ini terdapat dua syarat dalam melakukan pemidanaan yang dapat dilakukan yaitu perbuatan lahiriah yang dilarang atau biasa disebut dengan actus reus dan juga sikap batin yaing biasa disebut dengan mens rea. Unsur kesalahan merupakan unsur yang terpenting atau dapat dikatan unsur utama dalam pertangungjawaban hal ini dikarenakan tanpa adanya kesalahan seseorang tidak mungkin dapat dipidana. Dalam Kitab Undang-Undang Hukum Pidana tidak mengatur secara jelas konsep pertangungjawaban pidana yang diterapkannya, banyak sekali dalam pasal-pasal dalam kuhp menyebutkan kesalahan berupa kesengajan atau kealpaan dengan begitu maka diperlukan pembuktian yang dilakukan oleh pegadilan dengan begitu dapat mengetahui unsur kesalahan dan kelfaatn yang dilakukan.

Unsur-unsur yang ada dalam pertanggungjawaban pidana yang harus terpenuhi agar seseorang dapat dimintai pertangungjawaban adalah:

1. Adanya tindak pidana

${ }^{11}$ Moeljatno, Asas-asas Hukum Pidana (Rineka Cipta 2008).[165]. 
Perbuatan pidana merupakan unsur yang penting dan tindakan tersebut merupakan tindakan yang dilarang oleh Undang-Undang sesuai dengan asas legalitas yang berbunyi nullum delictum nulla poena sine praevia lege poenali yang diartikan seseorang tidak mungkin dipidana hanya dengan pikirannya saja. Di Indonesia orang tidak dapat dipidana hanya berdasarkan pada keadaan batin seseorang diperlukan perbuatan yang kongkrit dan tampak jelas sesuai dengan asas cogitationis poenam nemo patitur yang artinya orang tidak dapat dipidna han dengan pikiranya saja. ${ }^{12}$

2. Kesalahan

Pada perbuatan yang dilakukan tersebut mendapatkan celaan. Dan kesalahan dapat diartikan sebagai artian normatif yaitu kesalahan yang dipandang sebagai kesalahan yang ada dalam norma hukum dalam hal ini dobagi menjadai dua yaitu kesalahan sebagai kesengajaan atau kesalahan sebagai kealpaan. Kesengajaan adalah hal yang tidak dapat dipidahkan dari kesalahan, menurut pendapat dari Moeljatno kesalahan adanya hubungan antara batin dan pikiran dengan perbuatan yang dilakukan oleh seseorang. Seseorang yang melakuan tindakan dengan kesengajaan harus menghendaki akibat yang ditimbulkan dari perbuatan yang dilakukannya. Bentuk dari kesengajaan ini ada 3 (tiga) yaitu kesengajaan sebagai bentuk dalam kesengajaan ini menghendaki kelalaian suatu kewajiban hukum dan dapat menimbukkan akibat dari perbuatannya, kesalahan sebagai kemungkinan dalam kesengajaan ini pelaku mengetahui akibat lain yang mungkin akan ditimbulkan dari perbuatan yang dilakukan dan akibat dari perbuatan tersebut tidak diinginkan, kesengajaan sebagai kepastian dalam kesengajaan ini dalam perbuatan yang dilakukan menimbulkan akibat lain dan akibat tersebut bukan termasuk dalam akibat yang dituju. ${ }^{13}$

Dalam tindak pidana makar yang mengunakan media sosial debagai sarananya dikategorikan sebagai concursus, concursus merupakan terjadinya dua atau lebih

${ }^{12}$ Frans Maramis, Hukum Pidana Umum dan Tertulis di Indonesia (Raja Grafindo Persada 2012). [85].

${ }^{13}$ Moeljatno, Perluasan Pidana dan Pertanggungjawaban dalam Hukum Pidana (Bima Aksara 1983).[309]. 
tindak pidana yang dilakukan seseorang dan tindak pidana awal belum mendapat atau belum dijatuhi hukuman atau pidana terdapat 3 (tiga) bentuk concursus yaitu Concursus realis yang terdapat dalam Pasal 65 , Concursus Idealis yang tedapat dalam Pasal 63 dan Perbuatan Berlanjut yang terdapat dalam Pasal 64. penjatuhan pidana dalam sistem Concursus adalah sistem hisap jika dalam peraturan yang dikenakan terdapan ancaman pidana yang berbeda maka yang dikenakan adalah yang lebih berat dan bila aturan yang dikenakan adalah aturan umum dan khusus maka yang dijatuhkan adalah atauran khusus. ${ }^{14}$

Alat bukti dalam KUHP sesuai dengan pasal 183 KUHP dalam menjatuhkan hukuman pidana bila terdapat sekurang-kurangnya 2 alat bukti,alat buti yang dikasud adalah keterangan saksi, keterangan ahli, surat dan pentunjuk dan keterangan terdakwa. Alat buti elektronik diakui dalam persidangan indonesia adalah sesuai dengan yang diatur dalam Pasal 5 ayat (1) Undang-Undang ITE bahwa informasi dan tau dokumen elektronik atau hasil cetak merupakan alak bukti yang sah. ${ }^{15}$

Ratio decidendi adalah format yang ada dalam putusan hakim dan dinyatan dalam proposisi hukum, hubungan antara ratio decidendi dengan putusan hakim sangat erat dikarenakan putusan hakim berisikan argumen-argumen berdasarkan pasal-pasal yang berkaitan dengan perkara yang ditanganinya dan putusan tersebut dijadikan akta penutup perkara hukum dari hakim. Pada Putusan Nomor 1116/ Pid.B/2019/PN Jkt.Pst dan Putusan Nomor 211/Pid.B/2020 .

Pada Putusan Putusan Nomor 1116/Pid.B/2019/PN Jkt.Pst dengan terdakwa Hermawan Susanto sudah terdapat niat didalamnya sesuai dengan Pasal 53 yang diartikan sebagai kesengajaan dan diperlukan pembuktian apakah kesengajan dengan niat dikarenakan terdakwa sadar mengucapkan kalimat tersebut. Menurut pendapat dari Moeljatno kesengajaan harus diaplikasikan dengan perbuatan dan perbuatan tersebut harus menimbulkan suatu akibat, jika dilihat dari kasus terseut

\footnotetext{
${ }^{14}$ Fahrurrozi dan Abdul Rahman Salman Paris, 'Tinjauan Tentang Sistem Pemidanaan Dalam Perbarengan Tindak Pidana Menurut KUHP’, (2018), Vol. 9 Media Keadilan.[5].

${ }^{15}$ Undang-Undang Nomor 11 Tahun 2008 Tentang Informasi dan Transaksi Elektronik (Lembaran Negara Republik Indonesia Tahun 2008 Nomor 58).
} 
terdakwa dengan sadar menguvapkan kalimat yang mengandung usnsur tindak pidana makar dan dengan dilontarkan kata-kata tersebut dapat memprovokasi orang lain yang melihat video terdakwa tersebut. ${ }^{16}$ Tindakan yang dilakukan oleh terdakwa dalama video tersebut sesuai dengan Pasal 104 KUHP yang memiliki tujuan untuk membunuh kepala negara dan mengakibatkan kepala negara tidak dapat menjalankan tugasnya dan kata-kata yang dilontarkan oleh terdakwa mempunyai tujuan untuk membunuh kepala negara dan pengucapannya dilakukan beberapa kali oleh terdakwa.

Selain dapat dikenakan tindak pidana makar terdakwa juga dapat dikenai Pasal 27 ayar (4) Undang-Undang Tentang Informatika dan Transaksi Elektronik dimana terdakwa membuat dapat diaksesnya informasi elektronik yang memiliki muatan pemerasan dan atau pengancaman dalam kalimat yang diucapkan oleh terdakwa dalam video tersebut. Yang dilakukan tersebut dapat juga dikenai concursus Idealis karean yang dilakukan adalah tindakan yang dapat dikenai beberapa pasal yaitu pengancaman membunuh presiden atau pasal makar dengan media yang digunakan maka dapat dikenai juga Undang-undang Tentang Informatika dan Transaksi Elektronik, dalam sistem pemidanaannya mengunakan sistem pemidanaan dicari yang lebih berat pidna pokoknya karena yang lebih berat adalah tindak pidana makar maka makar yang diterapkan didalamnya.

Dalam Putusan Nomor 211/Pid.B/2020 dengan terdakwaAbner Litamahuputty dalam putusan ini niat yang ingin dicapai oleh pelaku sudah terpenuhi dengan dibawanya bendera yang bukan merupakan bendera kebangsaan Republik Indonesia yang dibawa tidak lain adalah bendera Republik Maluku Selatan. Dengan dipamerkanya bendera tersebut didepan umum dapat dikategorikan sebagai persiapan, perbuatan yang dilakukan oleh terdakwa mausk dalam kategori pasal 106 KUHP yaitu makar dengan tujuan untuk menjadikan negara merdeka dan berdaulat lepas dari NKRI hal ini dapat dilihat dapat dilihat dengan terdakwa ingin melepaskan terdakwa dari kantor polisi. Terdakwa juga melakukan permufakatan

\footnotetext{
${ }^{16}$ Moeljatno, Hukum Pidana Delik-Delik Percobaan dan Delik-Delik Penyertaan, Op.Cit.
} [19-20]. 
yang ada dalam Pasal 110 KUHP terdapat dalam ayat (1) merupakan permufakatan untuk melakukan kejahatan yang ada dalam Pasal 104, Pasal 106, Pasal 107, Pasal 108 KUHP dan dalam Pasal 110 KUHP ayat (1) walaupun tindak pidananya belum terjadi danjuga masih berupa kesepakatan yang dilakukan ole terdakwa dengan kedua orang saksi yang terjadi masih berupa persiapan atau kehendak terdakwa tetap dapat dikenai sama dengan orang yang melakukan tindak pidana yang ada dalam pasal 106 KUHP.

\section{Kesimpulan}

Tindak pidana makar dalam KUHP diatur dalam Pasal 104, Pasal 106 dan Pasal 107 , berkembangnya media sosial juga berkembang pula tindak pidana yang dilakukan oleh masyarakat sama halnya dengan tindak pidana makar dimana banyak sekali tindak pidana makar yang dilakukan mengunakan media sosial sebagai sarananya. Makar mengunakan media sosial ini dilakukan dapat berupa opini,mengungah video atau membagikan sesuatu yang menurut pasal dalam KUHP dapat dikategorikan sebagai tindak pidana makar karena media sosial merupakan ruang publik virtual sehingga masyarakat dapat mengaksesnya dengan sangat cepat. Terdapat kasus-kasus yang mengunakan media sosial sebagai sarana dalam melakukan tindak pidana makar sebagi contohnya Putusan Nomor 1116/ Pid.B/2019/PN Jkt.Pst yang meyebar luaskan video uangahan berupa keinginan untuk membunuh kepala negara.

\section{Daftar Bacaan}

\section{Buku}

Charlie Rudyat, Kamus Hukum (Tim pustaka Mahardika 2013).

Djoko Prakoso, Tindak Pidana Makar Menurut KUHP (Ghalia Indonesia 1985).

Frans Maramis, Hukum Pidana Umum dan Tertulis di Indonesia (Raja Grafindo Persada 2012).

Moeljatno, Asas-asas hukum pidana (Rineka Cipta 2008). 
Moeljatno, Hukum Pidana Delik-Delik Percobaan dan Delik-Delik Penyertaan (PT Bina Aksara 1983).

Moeljatno, Perluasan Pidana dan Pertanggungjawaban dalam Hukum Pidana (Bima Aksara 1983).

Rulli Nasrullah, Media Sosial : PerspektifKomunikasi, Budaya, dan Sosioteknologi (Remaja Rosdakarya 2017).

\section{Jurnal}

Erdianto Effendi, 'MAKAR DENGAN MODUS MENGGUNAKAN MEDIA SOSIAL'(2019) Jurnal Hukum Pidana Dan Pembangunan Hukum.

Fahrurrozi dan Abdul Rahman Salman Paris, 'Tinjauan Tentang Sistem Pemidanaan Dalam Perbarengan Tindak Pidana Menurut KUHP' (2018) Media Keadilan.

Prima Angkupi, 'Kejahatan Melalui Media Sosial Elektronik Di Indonesia Berdasarkan Peraturan Perundang-Undangan Saat Ini' (2014) Jurnal Mikrotik.

\section{Laman}

Ardito Ramadhan, 'Sejumlah Tokoh Terjerat Pasal Makar, Begini Pandangan Ahli Hukum' (Kompas.com,2019) https://megapolitan.kompas.com , Dikunjungi tanggal 15 Desember 2020.

Mahkamah Konstitusi RI, Putusan Nomor 7/PUU-XV/2017, https://mkri.id, diakses pada 10 Desember 2020.

Petrik Matanasi, “Sejarah Panjang Usaha Makar di Indonesia”, (Tirto.id, 2016 ) https://www.google.com/amp/s/amp.tirto.id diakses pada 27 Januari 2021.

\section{Peraturan Perundang-undangan}

Undang-Undang Nomor 11 Tahun 2008 Tentang Informasi dan Transaksi Elektronik (Lembaran Negara Republik Indonesia Tahun 2008 Nomor 58). 
Vicky Yuliana: Media Sosial Sebagai...

--halaman ini sengaja dibiarkan kosong-- 